\title{
Changes in the Quality of Black Mulberry and Blueberry Sherbets During Storage
}

\author{
Ahsen Rayman Ergün1, Yeliz Tekgül², Hamza Bozkır³, Taner Baysal ${ }^{1}$ \\ ${ }^{1}$ Food Engineering Department, Engineering Faculty, Ege University, 35100 Izmir, Turkey \\ ${ }^{2}$ Food Processing Department, Köşk Vocational School, Adnan Menderes University, 09570 Aydın, Turkey \\ ${ }^{3}$ Food Engineering Department, Engineering Faculty, Munzur University, 62100Tunceli, Turkey
}

\section{A R T I C LE IN F O}

\section{Research articles}

Received 18 July 2016

Accepted 06 December 2016

\section{Keywords:}

Black mulberry

Blueberry

Sherbet

Quality

Traditional drink

\begin{abstract}
A B S T R A C T
This study was evaluated the quality properties of traditional drink sherbets that are prepared from black mulberry and blueberry fruits. After production sherbets were investigated to determine their $\mathrm{pH}$, acidity, ${ }^{\circ}$ brix and colour values, total sugar, phenolic, anthocyanin and antioxidant contents. Moreover the sherbets stored at $4{ }^{\circ} \mathrm{C}$ during 2 months and the changes in these quality properties were examined per month. As a result statistically significant changes were observed in the quality properties of these sherbets of black mulberry and blueberry fruits which are known with their rich content of phytochemical compounds. The results show that in blueberry sherbet the degradation of phenolics was faster than black mulberry sherbet. Anthocyanins that are higher in black mulberry sherbets after production were preserved better in blueberry sherbets at the end of $2^{\text {nd }}$ month. $\mathrm{L}^{*}$ and $\mathrm{a}^{*}$ values decreased for blackberry and blueberry sherbets during storage. $b^{*}$ value decreased from 5.59 to 4.92 for blackberry sherbet while it increased from 0.62 to 0.79 for blueberry sherbet at the end of the storage time.
\end{abstract}

Corresponding Author:

E-mail: yeliz.tekgul@adu.edu.tr

\section{Introduction}

The black mulberry (Morus nigra), which originates from Iran, is cultivated for its fruits in South Europe, Southwest Asia and is the most important species in the Mediterranean countries (Tutin, 1996). The black mulberry (Turkish name 'Kara Dut') is widely grown in Turkey (Yaltirik, 1982). Along with Mediterranean conditions, Northeast part of Turkey, in particular Coruh valley has notable populations of black mulberry, which have been cultivated in gardens for their delicious edible fruits (Ercisli and Orhan, 2007).

Blueberry fruits belong to the genus Vaccinium, fam (Grace and et al., 2009). The blueberry (Vaccinium spp.) is a fruit native to North America and Europe, where it is widely cultivated and commercialized (Prior et al., 1998).

Berries are rich in phenolic compounds, such as phenolic acids, tannins, stilbenes, flavonoids and anthocyanins, but berries, in particular, have been the focus of considerable research regarding their anthocyanin-rich properties and according to Seeram (2008), there are many studies claim that the dietary intake of berry fruits has a positive and profound impact on human health, performance, and disease (Rios de Souza and et al., 2014). Blueberry and mulberry juice prevent obesity with the rich content of anthocyanins and phenolics (Wu et al., 2013). In addition in previous studies, antimicrobial activity of these fruits and juices on some microorganisms were investigated (Yang et al., 2014).

The red-coloured fruits which taste very pleasant when eaten fresh also have other uses as marmalades, juices, liquors, natural dyes and in the cosmetics industry (Ercisli and Orhan, 2007).

Sherbet is sweet and served chilled. Popular sharbats are made of one or more of the following: rose water, sandalwood, bael, gurhal (Hibiscus), lemon, orange, mango, pineapple, and falsa (Grewia asiatica). Most of the sharbats are very common in Indian, Turkish, Iranian, Arab, Afghan, Pakistani, and Bangladeshi homes. Black mulberry and Blueberry Sherbets are the traditional foods of İzmir (Turkey).

There are several studies about these fruits but the traditional drink sherbet has not been investigated before. The aim of this study was to evaluate the changes in the quality of black mulberry and blueberry sherbets during storage. 


\section{Materials and Methods}

\section{Preparation of Black mulberry and Blueberry Sherbets}

Black mulberry and blueberry sherbets were produced at Yudumla Sherbet Food Marketing and Industry. The fruits were processed after the pretreatment such as washing and sorting. After addition of sugar mashing was made, citric acid was added then pasteurization was made at $85^{\circ} \mathrm{C}$, for $10 \mathrm{~min}$. Then the sherbets were hot filled and cooled before storage. The flow charts were shown in figure 1 .

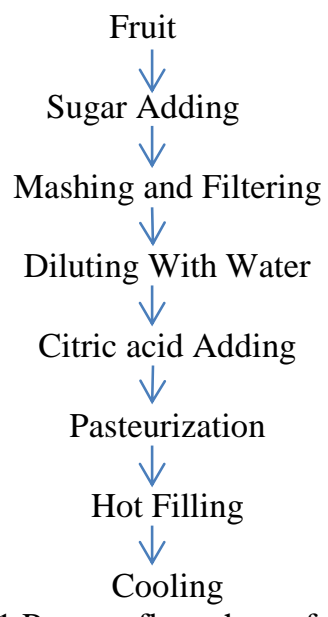

Figure 1 Process flow chart of sherbets

\section{Methods of Analyses}

Quality characteristics were investigated by physical and chemical analyses. Samples were analysed to determine the following: $\mathrm{pH}$ values were determined with pH meter (WTW InoLab, Weilheim, Germany).

Total acidity was determined by means of a potentiometric titration of the acidity of the juice by placing $10 \mathrm{~mL}$ of juice into $90 \mathrm{~mL}$ deionized water after filtration $10 \mathrm{~mL}$ filtrate was taken to titration, with a solution of $0.1 \mathrm{~N} \mathrm{NaOH}$ up to $\mathrm{pH} 8.1$. The results were expressed as $\mathrm{g} / 100 \mathrm{~mL}$ with reference to citric acid (Anon, 1995).

The total soluble matter ( ${ }^{\circ}$ Brix) of juices was measured with a refractometre at $20^{\circ} \mathrm{C}$ (RFM 330 Bellingham + Stanley Limited, Tunbridge Wells, Kent, UK) (Anon, 1995).

Total sugar was determined according to the LuffSchoorl method (Lees, 1975). No reducing sugar (sucrose) content was calculated according to the relationship sucrose $=$ [total sugar - reducing sugar $]$ x 0.95 .

Total phenolic content was measured using the FolinCiocalteau method (Singleton and Rossi, 1965). Results were expressed as milligrams of gallic acid equivalents per gram of fresh weight.

Total anthocyanin content was determined with the $\mathrm{pH}$ differential method (Wrolstad, 1976) and expressed as milligrams of cyanidin-3-glucoside equivalents per gram of fresh weight, on the basis of the molar absorptivity (29.600) of cyn-3-glu for blackberry. Calculations were based on malvidin-3-glucoside with molar absorptivity 28.000 for blueberry. All spectrophotometric analyses were performed by using Varian Cary 50 Scan (Australia) model spectrophotometer.

Total antioxidant activity of juices was determined by the ABTS (2,2-azinobis(3-ethylbenzothiazoline-6sulfonic acid) diammonium salt) assay (Re et al., 1999). The method gives a measure of the antioxidant activity of the juice, determined by the decolorization of the ABTS (Sigma-Aldrich Corp.) preformed by a reaction with potassiumpersulfate, and monitoring the reduction of the radical cation as the percentage inhibition of absorbance at $734 \mathrm{~nm}$ during $6 \mathrm{~min}$. The Trolox equivalent antioxidant capacity (TEAC) is the concentration of antioxidant giving the same percentage inhibition of absorbance of the radical cation at $734 \mathrm{~nm}$ as $1-\mathrm{mM}$ Trolox (Fluka Chemical, Switzerland) solution. The TEAC was obtained by the ratio between the gradient of the plot of the absorbance inhibition percentage compared with the concentration for the analyzed antioxidant and the corresponding gradient of the plot for Trolox.

The colour $\left(\mathrm{L}^{*}, \mathrm{a}^{*}, \mathrm{~b}^{*}\right)$ values were measured at HunterLab Colourflex colourimetre (Hunter Associates Laboratory Inc., Reston, VA, USA).

Statistical analyses were performed by analysis of variance (ANOVA) using the software SPSS 16 (SPSS Inc., Chicago, IL, USA) with Duncan test to evaluate the differences between months at level of significance $(\mathrm{P} \leq 0.05)$. Each experiment was repeated at least three times; means and standard deviations of results were calculated.

\section{Results and Discussion}

Physical and chemical properties of black mulberry sherbet were investigated during 2 months of storage at refrigerator conditions. Results of physical and chemical analyses were shown in table 1 for the samples of black mulberry sherbet.

$\mathrm{pH}$ value and acidity did not change significantly during storage $(\mathrm{P}>0.05)$. There are limited studies about black mulberry beverage (sherbet or drink) but previous studies were focused on the properties of black mulberry fruit. For example Ercişli and Orhan (2008) who investigated the physico-chemical characteristics of black mulberry cultivars found that the $\mathrm{pH}$ values of black mulberries vary between 3.43-3.66 which are comparable with our study. Gündoğdu et al. (2011) determined the acidity of mulberry species as $1.084 \pm 0,003 \%$ as citric acid for black mulberry fruit. The $\mathrm{pH}$ value was found as 3.30 and the acidity as $1.42 \%$ in the research of Kara and Ercelebi (2013) who studied with the Urmu mulberry juice concentrate.

${ }^{\circ}$ Brix value didn't change during storage. The change in the total sugar content was statistically not significant ( $P>0.05)$. Aramwit et al. (2010) found the total sugar content as $7.60 \pm 1.80 \mathrm{~g} / 100 \mathrm{~g}$ for purple, $5.1 \pm 1.4$ for purple- red and $1.8 \pm 0.8$ for red coloured mulberries. Gundogdu et al. (2011) reported that the total sugar content was changed between 10.4 $\pm 0.1-13.2 \pm 0.1(\mathrm{~g} / 100$ g) and they stated that glucose $(52 \%)$ and fructose $(48 \%)$ composed main part of the sugar composition whereas sucrose is only the $1 \%$ part of the total sugar in Morus nigra black mulberry fruit. 
Table 1 Changes in the quality of black mulberry sherbet during storage

\begin{tabular}{l|ccc}
\hline \multicolumn{1}{c|}{ Analyses } & 0. day & $30^{\text {th }}$ day & $60^{\text {th }}$ day \\
\hline pH & $3.75 \pm 0.01^{\mathrm{a}}$ & $3.75 \pm 0.02^{\mathrm{b}}$ & $3.75 \pm 0.01^{\mathrm{c}}$ \\
Acidity (\%) & $0.47 \pm 0.10^{\mathrm{a}}$ & $0.48 \pm 0.01^{\mathrm{b}}$ & $0.48 \pm 0.01^{\mathrm{c}}$ \\
Total sugar (\%) & $18.17 \pm 0.04^{\mathrm{a}}$ & $18.15 \pm 0.07^{\mathrm{b}}$ & $18.13 \pm 0.04^{\mathrm{c}}$ \\
${ }^{\circ}$ Brix & $18.85 \pm 0.07^{\mathrm{a}}$ & $18.80 \pm 0.14^{\mathrm{b}}$ & $18.70 \pm 0.14^{\mathrm{c}}$ \\
Phenolic content (ppm) & $383.98 \pm 0.25^{\mathrm{a}}$ & $299.98 \pm 0.40^{\mathrm{b}}$ & $199.90 \pm 0.20^{\mathrm{c}}$ \\
Anthocyanin content (mg cy-3-glu/g) & $300 \pm 0.10^{\mathrm{a}}$ & $250 \pm 0.12^{\mathrm{b}}$ & $150 \pm 0.15^{\mathrm{c}}$ \\
Antioxidant capacity (TEAC mM trolox/ml) & $12.5 \pm 0.20^{\mathrm{a}}$ & $11.4 \pm 0.10^{\mathrm{b}}$ & $9.2 \pm 0.30^{\mathrm{c}}$ \\
$\mathrm{L}^{*}$ & $6.96 \pm 0.07^{\mathrm{a}}$ & $6.75 \pm 0.01^{\mathrm{b}}$ & $6.24 \pm 0.01^{\mathrm{c}}$ \\
$\mathrm{a}^{*}$ & $19.49 \pm 0.19^{\mathrm{a}}$ & $18.07 \pm 0.54^{\mathrm{b}}$ & $17.86 \pm 0.60^{\mathrm{b}}$ \\
$\mathrm{b}^{*}$ & $5.59 \pm 0.29^{\mathrm{a}}$ & $5.36 \pm 0.35^{\mathrm{b}}$ & $4.92 \pm 0.30^{\mathrm{c}}$ \\
\hline${ }^{\mathrm{a} \text { toc }}$ Different lower case letter in the same line for each month indicates significant differences amongst samples during storage $(\mathrm{P}<0.05)$.
\end{tabular}

${ }^{\mathrm{c}}$ Different lower case letter in the same line for each month indicates significant differences amongst samples during storage $(\mathrm{P}<0.05)$.

Phenolics which are important with the antioxidant, antimutagenic and anticarcinogenic properties, are found in high amounts in deep-colored fruits. The total phenolic content for different cultivars of black mulberries was ranged between 1943 and $2237 \mathrm{mg}$ gallic acid equivalents/100g fresh mass (Ercişli and Orhan, 2007). Kara and Ercelebi (2013) studied with the Urmu mulberry juice concentrate and found the total phenolics as 2650 (mg GAE/L). We found this content as $383.98 \pm 0.25 \mathrm{ppm}$ in the sherbet. Phenolic compounds showed a degradable character during storage. The difference between the values were statistically significant $(\mathrm{P}<0.05)$. In a different study the blackberry-blueberry fermented beverage was studied. They determined the total phenolics of blackberry wine as $4029.0 \pm 68.4$ (mg $\left.\mathrm{EAE}^{2}\right) / \mathrm{L}$. Altuner and Tokusoglu (2013) demonstrated that phenolic compound composition in fruits is affected by some intrinsic factors, such as using different genus, species or cultivars, and extrinsic factors, such as the time of the collection of fruits, location, environmental factors and storage. Besides these intrinsic and extrinsic factors, some food-processing technologies can also affect the plant phenolics' composition They treated the juice with high hydrostatic pressure and found that this method preserves the compounds well after processing.

Anthocyanins (mg cy-3-glu/g fw) having a role in the colour of berry fruits, and this phytochemicals are also known with positive health effects by their antioxidant properties (Johnson et al., 2013). Anthocyanins were decreased by half at the end of $2^{\text {nd }}$ month compared to the initial value of black mulberry sherbet. Similar to phenolics, anthocyanins are highly perishable compounds. Fazaeli et al. (2013) studied with black mulberry juice concentrate at $42^{\circ}$ Brix which is treated with conventional and microwave heating, results showed that anthocyanin degradation and consequently decrease in antioxidant activity were more pronounced in rotary evaporation compared to microwave heating method. Nikkhah et al. (2007) emphasized that cyanidin-3-glucoside which is common anthocyanin in blackberry has also been reported to have the highest antioxidant capacity of 14 different anthocyanin tested (Wang et al., 1997; Mazza and Miniati, 1993). They also indicated that lowering water activity with sugar and especially sucrose concentration of $20 \%$ has a protective effect on anthocyanins, but higher concentrations has negative effect. If the sugar content of the sherbet was taken into consideration the degradation of total anthocyanins could be much more slower rather than to be a half. But on the other hand, Hellstrom et al. (2013) who studied the stability of anthocyanins in blackcurrent, chokeberry, bilberry and crowberry juices stored at different temperatures, decided that the anthocyanin stability was effected by a number of factors including the type of anthocyanin, the origin of the juice, and especially the storage temperature. They also indicated that in the berry smoothie the total anthocyanin content was $40.3 \pm 1.2 \mathrm{mg} / 100 \mathrm{ml}$ quantified as cyanidin 3glucoside equivalents. They explained that the commercial berry juice drinks had much lower anthocyanin contents than the other berry juice samples. The reason for this situation is their rather low juice content but probably also because of the intense processes applied commonly in the food industry. Anthocyanin degradation was faster in the commercial juice drinks stored at room temperature than in the smoothie stored at $4^{\circ} \mathrm{C}$. Indeed, they explain the anthocyanin decrease with the changes in $\mathrm{pH}$. In the commercial berry juice drinks the initial $\mathrm{pH}$ value (approximately 2.9) was lower and therefore, more favourable for anthocyanins than in the laboratory-made juices $(\mathrm{pH}$ 3.3-3.5). Similar to their study, we can say that the black mulberry sherbet has a $\mathrm{pH}$ value of 3.75 so the degradation was faster.

Antioxidant capacity due to phenolic and anthocyanin content decreased from $12.5 \pm 0.2$ to $9.2 \pm 0.30$ TEAC mM trolox/ml sherbet. Gündoğdu et al., (2011) found the total antioxidant capacity of black mulberry as $13.999 \pm 0.008$ TEAC $\mu \mathrm{mol} \mathrm{TEg}-1$ fw. In another reaserch the antioxidant contents were changed between 6.8-14.4 TEAC (mmol TE/g fw) for black mulberry fruits (Ozgen et al., 2009).

Color of berry type fruits were provided by the anthocyanin compounds. These compounds can be intensive on the skin or leaves of the fruits (Riihinen et al., 2008). It was stated that fruit color values were changes in the ranges for $\mathrm{L}^{*}, \mathrm{a}^{*}$ and $\mathrm{b}^{*}$ value as 14.79 17.47, 9.18-17.30 and 2.43-4.86 respectively (Ercişli and Orhan, 2008). Aramwit et al. (2010) measured the red colored mulberries and reported the lightness, redness and blueness to be as $27.75 \pm 5.32,20.62 \pm 3.56,9.28 \pm 2.87$ respectively. The $\mathrm{L}^{*}$ value was lower in the sherbet. Redness was found as $19.49 \pm 0.19$ and decreased during storage. But this decrease is not statistically significant 
$(\mathrm{P}>0.05)$. The $\mathrm{b}^{*}$ value was found in the range of 5.594.92. The decreases can be explained by the degradation of colour pigments. Anthocyanins especially Cyanidin $(\mathrm{R} 1=\mathrm{OH}, \mathrm{R} 2=\mathrm{H})$ which is the dominant one in the black berries (Hellstrom et al., 2013; Bae and Suh, 2007) was instable. Due to losses in anthocyanins the colour was affected negatively.
Chemical and physical characteristics of blueberry sherbets were investigated and shown in the table 2 . In blueberry sherbet samples $\mathrm{pH}$ value was lower compared to black mulberry sherbet. Giovanelli \& Buratti (2009) who studied with blueberry indicated that $\mathrm{pH}$ value was in the range of 2.92-3.22. Giovanelli et al. (2013) found the $\mathrm{pH}$ value of blueberry as $3.48 \pm 0.02$. Acidity and $\mathrm{pH}$ value didn't change during the storage time.

Table 2 Changes in the quality of blueberry sherbet during storage

\begin{tabular}{l|ccc}
\hline \multicolumn{1}{c|}{ Analyses } & 0. day & $30^{\text {th }}$ day & $60^{\text {th }}$ day \\
\hline $\mathrm{pH}$ & $2.29 \pm 0.06^{\mathrm{a}}$ & $2.30 \pm 0.06^{\mathrm{b}}$ & $2.31 \pm 0.06^{\mathrm{c}}$ \\
Acidity (\%) & $0.41 \pm 0.01^{\mathrm{a}}$ & $0.41 \pm 0.01^{\mathrm{b}}$ & $0.41 \pm 0.01^{\mathrm{c}}$ \\
${ }^{\circ}$ Brix & $18.95 \pm 0.07^{\mathrm{a}}$ & $18.90 \pm 0.07^{\mathrm{b}}$ & $18.88 \pm 0.10^{\mathrm{c}}$ \\
Total sugar (\%) & $18.74 \pm 0.06^{\mathrm{a}}$ & $18.65 \pm 0.07^{\mathrm{b}}$ & $18.68 \pm 0.11^{\mathrm{c}}$ \\
Phenolic content (ppm) & $536.79 \pm 0.15^{\mathrm{a}}$ & $435.34 \pm 0.10^{\mathrm{b}}$ & $100 \pm 0.12^{\mathrm{c}}$ \\
Anthocyanin content (mg cy-3-glu/g) & $200 \pm 0.20^{\mathrm{a}}$ & $165 \pm 0.15^{\mathrm{b}}$ & $160 \pm 0.17^{\mathrm{c}}$ \\
Antioxidant capacity (TEAC mM trolox/ml) & $17.93 \pm 0.02^{\mathrm{a}}$ & $10 \pm 0.04^{\mathrm{b}}$ & $7.86 \pm 0.01^{\mathrm{c}}$ \\
$\mathrm{L}^{*}$ & $4.20 \pm 0.09^{\mathrm{a}}$ & $4.68 \pm 0.01^{\mathrm{b}}$ & $3.95 \pm 0.28^{\mathrm{c}}$ \\
$\mathrm{a}^{*}$ & $11.66 \pm 0.01^{\mathrm{a}}$ & $11.46 \pm 0.02^{\mathrm{b}}$ & $10.49 \pm 0.03^{\mathrm{c}}$ \\
$\mathrm{b}^{*}$ & $0.62 \pm 0.10^{\mathrm{a}}$ & $1.12 \pm 0.01^{\mathrm{b}}$ & $0.79 \pm 0.20^{\mathrm{c}}$ \\
\hline${ }^{\mathrm{a} \text { toc }}$ Different lower case letter in the same line for each month indicates significant differences amongst samples during storage (P<0.05).
\end{tabular}

${ }^{\mathrm{c}}$ Different lower case letter in the same line for each month indicates significant differences amongst samples during storage $(\mathrm{P}<0.05)$.

${ }^{\circ}$ Brix value was decreased to $18.68 \%$ at the end of two months. It was indicated that blueberry has a ${ }^{\circ}$ Brix value in the range of 11.6-12.9. Giovanelli et al. (2013) found the ${ }^{\circ}$ Brix value as $11.4 \pm 0.4$. Soluble solid content was determined as $14.9 \pm 0.6$ by Gunathilake et al., (2014) in the blueberry juice. Sugar content was significantly decreased during 2 months of storage similar to black mulberry sherbet samples.

The losses in the phenolics increased after $1^{\text {st }}$ month, approximately $77 \%$ losses were determined after $1^{\text {st }}$ month. These compounds were susceptible to degradation during processing and storage (Syamaladevi et al., 2012). Giovanelli and Buratti (2009) found the total phenolics 251-298 (gallic acid $\mathrm{mg} / 100 \mathrm{~g}$ ) in different cultivars of blueberry. The phenolic content of blueberry was indicated as $317 \pm 18 \mathrm{mg} / 100 \mathrm{~g}$ (2013). Total polyphenols of partially concentrated to $15{ }^{\circ}$ Brix of blueberry juice has phenolic content of $2627 \pm 25 \mathrm{mg} \mathrm{GAE} / \mathrm{L} \mathrm{mg}$ gallic acid equivalent/L. Syamaladevi et al. (2012) found a $117 \%$ increase in the phenolic content of in canned blueberry syrup during 13 month of storage. They explain this increase to the improved extraction efficiency due to cell destruction during storage.

Anthocyanin content was lower compared to black mulberry sherbet. It was explained that there is relationship between the sugar content and anthocyanins due to the role of sugars in the anabolism of anthocyanins by Aramwit et al., (2010). It is possible to verify this opinion with the data that black mulberry sherbet has higher total sugar than blue berry sherbet samples initially. But during storage lower reduction of these compounds were obtained in the samples of blueberry sherbet. Giovanelli et al. (2013) indicated that total anthocyanin content for the blueberry was $97 \pm 10 \mathrm{mg} / 100$ g. Syamaladevi et al. (2012) found $73-79 \%$ decreases in anthocyanins in blueberry juices after 5 months of storage in comparison with 0 month of storage. Mohideen et al. (2015) investigated the effect of continuous ultrasonication on microbial counts and physico-chemical properties of blueberry (Vaccinium corymbosum) juice and showed that ultrasonic treatment did not change the total anthocyanin content of blueberry juice. It was previously highlighted that deterioration of anthocyanins can be effected by the enzymes such as polyphenoloxidase, peroxidase and B-glucosidase (Cano et al. 1997; Altuner and Tokuşoğlu, 2013).

The antioxidant activity decreased during storage and the difference between the antioxidant activities of samples were statistically significant $(\mathrm{P}<0.05)$. In a similar study; Syamaladevi et al. (2012) found in the canned blueberry syrup, total anthocyanins and total antioxidant activity decreased by up to 68 and $15 \%$ respectively. They observed that the antioxidant activity in canned blueberry syrup showed greater consistency than total anthocyanins and total phenolics during storage. They also researched the effect of blanching on the blueberries during the storage of juice, total antioxidant activity changed from $1^{\text {st }}$ month to $3^{\text {rd }}$ month as 9.49. The berries processed to juice without blanching have lower antioxidant values. The antioxidant activity was reduced from $11.14 \pm 0.18$ by $39.85 \%$ in blueberry juice stored under refrigerator for 10 days. In a different study researches investigated the blueberry by products and decided that acidification significantly reduced the total anthocyanin content, total polyphenols and antioxidant activities. In addition they demonstrated that by-products especially juice pomace and wine pomace still retained important phenolic concentrations and antioxidant activities (Su and Silva, 2006). 
Color values were shown in table 2 for the blueberry sherbet samples. $\mathrm{L}^{*}$ and $\mathrm{b}^{*}$ values were increased in the $1^{\text {st }}$ month and then decreased in the $2^{\text {nd }}$ month. $a^{*}$ value was more stable than the $\mathrm{L}^{*}$ and $\mathrm{b}^{*}$ values. Mohideen et al. (2015) found the colour values of blueberry juice comparable to our results as $\mathrm{L}^{*}: 3.03 \pm 0.03$ and $\mathrm{a}^{*}$ value: $15.49 \pm 0.39$. It is suggested that a decreases in $a^{*}$ values of berry juices are related to anthocyanin degradation and formation of Maillard reaction products (Aguilo-Aguayo et al., 2009; Mohideen et al., 2015).

\section{Conclusion}

In summary this study demonstrated that sherbets produced from black mulberry and blueberry fruits are rich in phenolic and anthocyanin compounds which have high antioxidant properties comparable with the raw fruits. These fruits and fruit products have health benefits associated with these nutritious phytochemicals. However these valuable compounds are favourable to deterioration reactions. At the end of storage at refrigerator conditions $\left(+4^{\circ} \mathrm{C}\right)$ the quality parameters were decreased significantly. It can be said that although blueberry drink has higher phenolic and antioxidant activity, the losses in these compounds are faster and higher than the black mulberry sherbet. Novel technologies such as ohmic heating, high hydrostatic pressure can be used for blocking phenolic and anthocyanin compounds loses that is caused from temperature.

\section{Acknowledgments}

The authors would like to thank the workers in Yudumla Sherbet Gıda Paz. San. ve Tic. Ltd. Şti. Işıkkent / İZMIR for their help.

\section{References}

Aguiló-Aguayo I, Oms-Oliu G, Soliva-Fortuny R, Martín-Belloso O. 2009. Changes in quality attributes throughout storage of strawberry juice processed by high-intensity pulsed electric fields or heat treatments LWT - Food Science and Technology, 42( 4) : 813-818.

Altuner EM and Tokusoğlu Ö. 2013. The effect of high hydrostatic pressure processing on the extraction, retention and stability of anthocyanins and flavonols contents of berry fruits and berry juices. International Journal of Food Science and Technology, 48: 1991-1997.

Anon. AOAC Method 932.12 solids (soluble) in fruit and fruit products, 1995. In Official methods of analysis of AOAC International, 37(1):15.

Aramwit P, Bang N, Srichana T. 2010. The properties and stability of anthocyanins in mulberry fruits. Food Research International, 43(4) :1093-1097.

Bae SH and Suh HJ. 2007. Antioxidant activities of five different mulberry cultivars in Korea. LWT, 40: 955-962.

Cano MP, Hernandez A, De Ancos B. 1997. High pressure and temperature effects on enzyme inactivation in strawberry and orange products. Journal of Food Science 62: 85-88.

Ercisli S and Orhan E. 2007. Chemical compsition of White (Morus alba) and black (Morus nigra) red (Morus rubra) mulberry fruits. Food Chemistry, 103: 1380-1384.
Ercisli S and Orhan E. 2008. Some physico-chemical characteristics of black mulberry (Morus nigra L.) genotypes from Northeast Anatolia region of Turkey Scientia Horticulturae, 116: 41-46.

Fazaeli M, Yousefi S and Emam-Djomeh Z. 2013. Investigation on the effects of microwave and conventional heating methods on the phytochemicals of pomegranate (Punica granatum L.) and black mulberry juices. Food Research International, 50: 568573.

Giovanelli G and Buratti S. 2009. Comparison of polyphenolic composition and antioxidant activity of wild Italian blueberries and some cultivated varieties. Food Chemistry, 112 (4) : 903908.

Giovanelli G, Brambilla A, Sinelli N. 2013. Effects of osmo-air dehydration treatments on chemical, antioxidant and morphological characteristics of blueberries LWT - Food Science and Technology, 54: 577-584.

Grace MH, Ribnicky Kuhn DMP, Poulev A, Logendra S, Yousef GG, Raskin I and Lila MA. 2009. Hypoglycemic activity of a novel anthocyanin-rich formulation from lowbush blueberry Vaccinium angustifolium Aiton. Phytomedicine, 16: 406-415.

Gunathilake KDPP and Li Juan Yu HP. 2014. Vasantha Rupasinghe Reverse osmosis as a potential technique to improve antioxidant properties of fruit juices used for functional beverages. Food Chemistry, 148: 335-341.

Gundogdu M, Muradoglu F, Gazioglu Sensoy RI and Yilmaz H. 2011. Determination of fruit chemical properties of Morus nigra L., Morus alba L. AnD Morus rubra L. by HPLC Scientia Horticulturae, 132 : 37-41.

Hellstrom J, Mattila P and Karjalainen R. 2013. Stability of anthocyanins in berry juices stored at different temperatures. Journal of Food Composition and Analysis, 31: 12-19.

Johnson SA and Arjmandi BH. 2013. Evidence for Anti-Cancer Properties of Blueberries: A Mini Review. Anti-Cancer Agents in Medicinal Chemistry, 13: 1142-1148.

Kara S and Alben Ercelebi E. 2013. Thermal degradation kinetics of anthocyanins and visual colour of Urma mulbery (morus nigra L.). Journal of Food Engineering, 116: 541-547.

Mazza G and Minitiati E. 1993. Introduction In Anthocyanin in Fruits, Vegetables and Grains. Boca raton. FL: CRC Press (Chapter 1) :1-28.

Nikkhah E, Khayamy M, Heidari R and Jamee R. 2007. Effect of Sugar Treatment on Stability of Anthocyanin Pigments in Berries. Journal of Biological Sciences, 7: 1412-1417.

Ozgen M, Serçe S and Kaya C. 2009. Phytochemical and antioxidant properties of anthocyanin-rich Morus nigra and Morus rubra fruits. Scientia Horticulturae, 119: 275-279.

Prior RL, Cao G, Martin A, Sofic E, McEwen J, O’Brien C, Lischner N, Kalt M, Ehlenfeldt W, Krewer G and Mainland CM. 1998. Antioxidant capacity as influenced by total phenolic and anthocyanin content, maturity, and variety of Vaccinium species. Journal of Agricultural and Food Chemistry, 46: 26862693.

Priscilla MR, Rosana SS, Andre' Jablonski, Simone H. Flo^res, Alessandro de O. Rios, Erna V. de Jong. 2014. Cold storage of blueberry (Vaccinium spp.) fruits and juice: Anthocyanin stability and antioxidant activity Journal of Food Composition and Analysis, 33: 111-116.

Re R, Pellegrini N, Proteggente A, Pannala A, Yang M and RiceEvans C. 1999. Antioxidant activity applying an improved ABTS radical cation decolarization assay. Free Radic Biol Med , 8, 26(9/10): 1231-1237.

Riihinen K, Jaakola L, Karenlampi S, Hohtola A. 2008. Organspecific distribution of phenolic compounds in bilberry (Vaccinium myrtillus) and 'northblue' blueberry (Vaccinium corymbosum x V. angustifolium). Food Chemistry, $110: 156-160$.

Rios de Souza V, Pereira PAP, Teodoro da Silva TL, Carlos de Oliveira Lima L, Pio R and Queiroz F. 2014. Determination of the bioactive compounds, antioxidant activity and chemical composition of Brazilian blackberry, red raspberry, strawberry, blueberry and sweet cherry fruits. Food Chemistry, 156: 362368. 
Seeram NP. 2008. Berry fruits: Compositional elements, biochemical activities, and the impact of their intake on human health, performance, and disease. Journal of Agricultural and Food Chemistry, 56: 627-629.

Singleton VL and Rossi JA. 1965. Colorimetry of total phenolics with phosphomolybdic-phosphotungstic acid reagents. Am. J. Enol. Vitic. 16: 144-158.

Su MS and Silva JL. 2006. Antioxidant activity, anthocyanins, and phenolics of rabbiteye blueberry (Vaccinium ashei) by-products as affected by fermentation. Food Chemistry, 97: 447-451.

Syamaladevi R, Andrews PK, Davies NM, Sablania TW SS. 2012. Storage effects on anthocyanins, phenolics and antioxidant activity of thermally processed conventional and organic blueberries. J.Sci.Food Agric., 92: 916-924.

Tutin NA, Burges AO, Chater JR, Edmondson VH, Heywood DM. 1996. Moore (Eds.), et al., Flora Europa, Psilotaceae to Platanaceae (2nd ed.), vol. 1, Cambridge University Press( in Australia) .
Wang H, Cao G and Prior R. 1997. Oxygen Radical Absorbing Capacity of Anthocyanins. Journal of Agric. Food Chem., 45: 304-309.

Wrolstad RE. 1976. Color and pigment analyses in fruit products Station Bulletin. Agricultural Experiment Station Oregon State, Corvallis, OR, 624: 1-17.

Wu T, Tang Q, Gao Z, Yu Z, Song H, Zheng X. 2013. Blueberry and Mulberry Juice Prevent Obesity Development in C57BL/6 Mice PLoS ONE, 8(10): 775-785.

Yaltirik F, Morus PH Davis (Ed.).Flora of Turkey. 1982. Edinburgh University Press, Edinburgh, UK, 7: 641-642.

Yang H, Hewes D, Salaheen S, Federman C and Biswas D. 2014. Effects of blackberry juice on growth inhibition of foodborne pathogens and growth promotion of Lactobacillus. Food Control, 37: 15-20. 